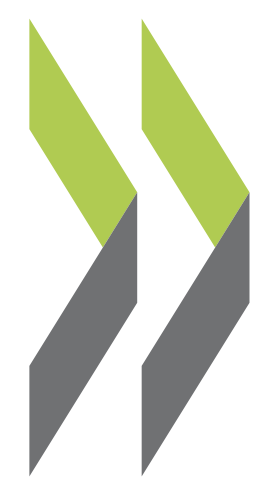

OECD Working Papers on International Investment 2004/04

\title{
"Indirect Expropriation" and the "Right to Regulate" in International Investment
}

\section{OECD}

Law 


\title{
OECD $\ll \bigcirc$ OCDE
}

DIRECTORATE FOR FINANCIAL AND ENTERPRISE AFFAIRS

WORKING PAPERS ON INTERNATIONAL INVESTMENT

Number 2004/4

\section{"INDIRECT EXPROPRIATION" AND THE "RIGHT TO REGULATE" IN INTERNATIONAL INVESTMENT LAW}

\author{
September 2004
}

This document, derestricted under the OECD Secretary General's responsibility, has been developed as an input to the Investment Committee's work aimed at enhancing understanding of "indirect expropriation" and the "right to regulate" in international investment law.

This document benefited from discussions and a variety of perspectives in the Committee. The document as a factual survey, however, does not necessarily reflect the views of the OECD or those of its Member governments. It cannot be construed as prejudging ongoing or future negotiations or disputes pertaining to international investment agreements.

This document was prepared by Catherine Yannaca-Small, Legal Advisor, Investment Division, Directorate for Financial and Enterprise Affairs. 


\section{"INDIRECT EXPROPRIATION" AND THE "RIGHT TO REGULATE" IN INTERNATIONAL INVESTMENT LAW}

\section{Introduction}

It is a well recognised rule in international law that the property of aliens cannot be taken, whether for public purposes or not, without adequate compensation. Two decades ago, the disputes before the courts and the discussions in academic literature focused mainly on the standard of compensation and measuring of expropriated value. The divergent views ${ }^{1}$ of the developed and developing countries raised issues regarding the formation and evolution of customary law. Today, the more positive attitude of countries around the world toward foreign investment and the proliferation of bilateral treaties and other investment agreements requiring prompt, adequate and effective compensation for expropriation of foreign investments have largely deprived that debate of practical significance for foreign investors.

Disputes on direct expropriation - mainly related to nationalisation that marked the $70 \mathrm{~s}$ and $80 \mathrm{~s}--$ have been replaced by disputes related to foreign investment regulation and "indirect expropriation". Largely prompted by the first cases brought under NAFTA, there is increasing concern that concepts such as indirect expropriation may be applicable to regulatory measures aimed at protecting the environment, health and other welfare interests of society. The question that arises is to what extent a government may affect the value of property by regulation, either general in nature or by specific actions in the context of general regulations, for a legitimate public purpose without effecting a "taking" and having to compensate for this act. One leading commentator suggests that the issue of definition of expropriation in this context may become the dominant issue in international investment law. $^{2}$

1. A number of developed countries endorsed the "Hull formula", first articulated by the United States Secretary of State Cordell Hull in response to Mexico's nationalisation of American petroleum companies in 1936. Hull claimed that international law requires "prompt, adequate and effective" compensation for the expropriation of foreign investments. Developing countries supported the Calvo doctrine during the 1960s and 1970s as reflected in major United Nations General Assembly resolutions. In 1962, the General Assembly adopted its Resolution on Permanent Sovereignty over Natural resources which affirmed the right to nationalise foreign owned property and required only "appropriate compensation". This compensation standard was considered an attempt to bridge differences between developed and developing states. In 1974, the UN General Assembly decisively rejected the Hull formula in favour of the Calvo doctrine in adopting the Charter of Economic Rights and Duties of States. While Article 2(c) repeats the "appropriate compensation" standard, it goes on to provide that "in any case where the question of compensation gives rise to a controversy, it shall be settled under the domestic law of the nationalising State and by its tribunals...". Nowadays, the Hull formula and its variations are often used and accepted and considered as part of customary international law.

2. Dolzer, "Indirect Expropriations: New Developments?" Article of the Colloquium on Regulatory Expropriation organised by the New York University on 25-27 April 2002; 11 Environmental Law Journal 64. 
Despite a number of decisions of international tribunals, the line between the concept of indirect expropriation and governmental regulatory measures not requiring compensation has not been clearly articulated and depends on the specific facts and circumstances of the case. However, while case-bycase consideration remains necessary, there are some criteria emerging from the examination of some international agreements and arbitral decisions for determining whether an indirect expropriation requiring compensation has occurred.

The present survey provides factual elements of information on jurisprudence, state practice and literature on this matter. It presents the issues at stake and describes the basic concepts of the obligation to compensate for indirect expropriation (Part I), reviews whether and how legal instruments and other texts articulate the difference between indirect expropriation and the right of the governments to regulate without compensation (Part II) and attempts to identify a number of criteria which emerge from jurisprudence and state practice for determining whether an indirect expropriation has occurred (Part III).

\section{Basic concepts of the obligation to compensate for indirect expropriation}

Customary international law does not preclude host states from expropriating foreign investments provided certain conditions are met. These conditions are: the taking of the investment for a public purpose, as provided by law, in a non-discriminatory manner and with compensation.

Expropriation or "wealth deprivation"3 could take different forms: it could be direct where an investment is nationalised or otherwise directly expropriated ${ }^{4}$ through formal transfer of title or outright physical seizure. In addition to the term expropriation, terms such as "dispossession", "taking", "deprivation" or "privation" are also used. ${ }^{5}$ International law is clear that a seizure of legal title of property constitutes a compensable expropriation.

Expropriation or deprivation of property ${ }^{6}$ could also occur through interference by a state in the use of that property or with the enjoyment of the benefits even where the property is not seized and the

3. "Wealth deprivation" is a term which according to Weston avoids most, if not all, of the major ambiguities and imprecision of the traditional terminology. See B. Weston "'Constructive Takings" under International Law: A Modest Foray into the Problem of 'Creeping Expropriation"”, Virginia Journal of International Law, 1975, Volume 16, pp. 103-175 at 112.

4. In general, expropriation applies to individual measures taken for a public purpose while nationalisation involves large-scale takings on the basis of an executive or legislative act for the purpose of transferring property or interests into the public domain.

5. Dolzer and Stevens, "Bilateral Investment Treaties", ICSID 1995 at 98.

6 In the context of international law, "property" refers to both tangible and intangible property. Under Article 1139 of the NAFTA, the definition of "investment" covers, among other things, "real estate or other property, tangible or intangible [emphasis supplied], acquired in the expectation or used for the purpose of economic benefit or other business purposes." Likewise, most BITs contain a relatively standard definition of investment that also covers intangible forms of property: "intellectual property and contractual rights". Source UNCTAD "Bilateral Investment Treaties in the Mid-1990s" 1998. See also the recently concluded US FTAs with Australia, Chile, Central America, Morocco and Singapore: "An action or series of actions by a Party cannot constitute an expropriation unless it interferes with a tangible or intangible property right or property interest in an investment".The IranUnited States Claims Tribunal stated that "[the claimants] rely on precedents in international law in which case measures of expropriation or takings, primarily aimed at physical property, have been deemed to comprise also rights of a contractual nature closely related to the physical property..." It has consistently rejected attempts made by Iranian respondents for a narrow interpretation of 
legal title to the property is not affected. The measures taken by the State have a similar effect to expropriation or nationalisation and are generally termed "indirect", "creeping", 7 or "de facto" expropriation, or measures "tantamount" to expropriation.

However, under international law, not all state measures interfering with property are expropriation. As Brownlie has stated, "state measures, prima facie a lawful exercise of powers of governments, may affect foreign interests considerably without amounting to expropriation. Thus, foreign assets and their use may be subjected to taxation, trade restrictions involving licenses and quotas, or measures of devaluation. While special facts may alter cases, in principle such measures are not unlawful and do not constitute expropriation" ${ }^{\text {" }}$. Similarly, according to Sornarajah ${ }^{9}$, non-

"property" and has confirmed that shareholder rights and contractual rights can be the object of expropriation Starret Housing Corp. v. Islamic Republic of Iran, 4, Iran-US Cl. Trib. Rep. 122, 15657 (1983), Amoco International Finance Corporation v. Iran, Award No 310-56-3 (14 July 1987), 15 Iran-US C.T.R. 189-289. Under the Protocol 1 of the European Convention on Human Rights, the concept of property is very broadly defined by reference to all the proprietary interests of an individual. It covers a range of economic interests: "movable or immovable property, tangible and intangible interests, such as shares, patents, an arbitration award, the entitlement to a pension, a landlord's entitlement to rent, the economic interests connected with the running of a business and the right to exercise a profession...".

One of the first instances in which the violation of an intangible property right was held to be an expropriation, was the Norwegian Ship-owners' case. Although the United States contended that it had requisitioned only ships and not the underlying contracts, the Tribunal found that a taking of property rights ancillary to those formally taken had occurred and required compensation. Nor. v. U.S., 1 R.I.A.A. 307, 332 (Perm. Ct. Arb. 1922). In the 1926 case of German Interests in Polish Upper Silesia - the Chorzow Factory case- the Permanent Court of International Justice found that the seizure by the Polish government of a factory plant and machinery was also an expropriation of the closely interrelated patents and contracts of the management company, although the Polish government at no time claimed to expropriate these. F.R.G. v. Pol., 1926 P.C.I.J. (ser. A) No 7 (May 1925).

However, certain intangible property rights or interests, by themselves, may not be capable of being expropriated, but may be viewed instead, as elements of value of business. In the 1934 Oscar Chinn case, the Permanent Court did not accept the contention that good will is a property right capable, by itself, of being expropriated. The P.C.I.J. found that a granting of a de facto monopoly did not constitute a violation of international law, stating that "it was unable to see in [claimant's] original position - which was characterised by the possession of customers - anything in the nature of a genuine vested right" and that "favourable business conditions and good will are transient circumstances, subject to inevitable changes". 1934 P.C. I. J. Ser A/B, no 63. In two more recent NAFTA cases, the NAFTA Tribunals addressed claims concerning market access and market share and suggested that these might be property rights for purposes of expropriation. In neither case, however, did the tribunal find that market access or market share could be capable themselves of being expropriated, nor did either tribunal find that an expropriation took place. See Pope \& Talbot, Inc v. Canada, Interim Award (June 26, 2000), paras. 96-98 and S.D. Myers, Inc. v. Canada, (November 13, 2000) Partial Award, 232. International Legal Materials 408, para. 232. See also e.g. G. White "Nationalisation of Foreign Property" 49 (1961); The Iran-United States Claims Tribunal: Its contribution to the Law of State Responsibility 196-97 n. 33 (Richard Lillich and Daniel Magraw editors, 1998).

7. On this point, Dolzer notes that, “"creeping expropriation' suggests a deliberate strategy on the part of the state, which may imply a negative moral judgement". See Dolzer, "Indirect Expropriation of Alien Property”, ICSID Review, Foreign Investment Law Journal, (1986) pp. 41-59 at 44.

8. Ian Brownlie, "Public International Law", Oxford University Press, 6th Edition, 2003 at 509. 
discriminatory measures ${ }^{10}$ related to anti-trust, consumer protection, securities, environmental protection, land planning are non-compensable takings since they are regarded as essential to the efficient functioning of the state.

As mentioned above, there is no generally accepted and clear definition of the concept of indirect expropriation and what distinguishes it from non-compensable regulation, although this question is of great significance to both investors and governments. As Dolzer and Stevens wrote:

"To the investor, the line of demarcation between measures for which no compensation is due and actions qualifying as indirect expropriations (that require compensation) may well make the difference between the burden to operate (or abandon) a non-profitable enterprise and the right to receive full compensation (either from the host State or from an insurance contract). For the host State, the definition determines the scope of the State's power to enact legislation that regulates the rights and obligations of owners in instances where compensation may fall due. It may be argued that the State is prevented from taking any such measures where these cannot be covered by public financial resources". ${ }^{11}$

As Higgins wrote in her study on the taking of property by the state, the issue can be further refined as the determination of who is to pay the economic cost of attending to the public interest involved in the measure in question. Is it to be the society as a whole, represented by the state, or the owner of the affected property? ${ }^{12}$

Nouvel has pointed out that in the case of nationalisation or direct expropriation, the dispossession to the detriment of a private person coincides with the appropriation to the profit of a public person; the measures tantamount to expropriation do not have this linkage. In the latter case, the reduction of the value of private property is not necessarily accompanied by an increase in public wealth. ${ }^{13}$

9. M. Sornarajah, "The International Law on Foreign Investment" (1994) at 283, Cambridge University Press.

10. It is an accepted principle of customary international law that where economic injury results from a bona fide non-discriminatory regulation within the police powers of the State, compensation is not required. A state measure will be discriminatory if it results "in an actual injury to the alien ...with the intention to harm the aggrieved alien" to favour national companies. See Dolzer and Stevens, op. cit. n. 5. The Restatement Third recognises the non-discrimination rule: "One test suggested for determining whether regulation and taxation program are intended to achieve expropriation is whether they are applied only to alien enterprises" "Restatement of the Law Third, the Foreign Relations of the United States," American Law Institute ,Volume 1, 1987, Section 712. The Iran-US Claims Tribunal recognised in the Amoco case that Iran owed compensation for expropriatory measures, and also acknowledged the rule of non-discrimination. The Award specifically states that: "discrimination is widely prohibited by customary international law in the field of expropriation," although the Tribunal found no discrimination in this case. Amoco see op. cit. n. 6 .

11. Dolzer and Stevens op. cit. n.5 at 99 .

12. R. Higgins "The Taking of Property by the State: Recent Developments in International Law" Recueil des Cours - Académie de Droit International, 1982, Vol. 176 at 276-77.

13. Yves Nouvel, «Les mesures équivalant à une expropriation dans la pratique récente des tribunaux arbitraux », Revue Générale du Droit International Public, 2002-1 pp. 80-102 at 89. 


\section{Legal instruments and other texts}

Protection against indirect expropriation has been included in various forms of international instruments. Literally all relevant treaties and draft treaties provide for indirect expropriation or measures tantamount to expropriation. However, most of them stay mute on the treatment of the noncompensable regulatory measures, with the exception of: the European Convention on Human Rights and Fundamental Freedoms (hereafter the European Convention on Human Rights), the recently concluded US-Free Trade Agreements and the new model US and Canada BITs. The OECD Draft Convention on the Protection of Foreign Property and the draft OECD Multilateral Agreement on Investment, while themselves silent on the non-compensable regulatory measures, were accompanied by commentaries which did address the issue. Other texts which addressed it are the Harvard Draft Convention on International Responsibility, and the Third Restatement of Foreign Relations of the United States which, while the work of scholars, not state practice, constitute an influential element of doctrine.

\section{A. Legal texts which include indirect expropriation without addressing non-compensable regulation}

Bilateral Investment Treaties contain brief and general indirect expropriation provisions which focus on the effect of the government action and do not address the distinction between compensable and non-compensable regulatory actions. For example, treaties entered by France refer to "measures of expropriation or nationalisation or any other measures the effect of which would be direct or indirect dispossession". The UK treaties provide that expropriation also covers measures "having effect equivalent to nationalisation or expropriation". Other treaties, such as some of those concluded by Sweden, refer to "any direct or indirect measure" or "any other measure having the same nature or the same effect against investments". The former United States Model BIT mentions "measures tantamount to expropriation or nationalisation". Several United States treaties are more specific on these measures: "any other measure or series of measures, direct or indirect, tantamount to expropriation (including the levying of taxation, the compulsory sale of all or part of an investment, or the impairment or deprivation of its management, control of economic value...". ${ }^{4}$

The 1992 World Bank Guidelines section IV (1) on "Expropriation and Unilateral Alterations or Termination of Contracts", state that : "A state may not expropriate or otherwise take in whole or in part a foreign private investment in its territory, or take measures which have similar effects, except where this is done in accordance with applicable legal procedures, in pursuance in good faith of a public purpose, without discrimination on the basis of nationality and against the payment of appropriate compensation".

The 1994 Energy Charter Treaty in its Article 13 provides that: "investments of investors of a Contracting Party in the Area of any other Contracting Party shall not be nationalized, expropriated or subjected to a measure or measures having effect equivalent to nationalization or expropriation" except where such measure complies with the rules of customary international law in this matter (public purpose, due process, non-discrimination and compensation).

Article 1110 of NAFTA protects against the expropriation of foreign investments with the following language:

14. See Dolzer and Stevens op. cit. no. 5 . 
1. No Party may directly or indirectly nationalise or expropriate an investment of an investor of another Party in its territory or take a measure tantamount to nationalisation or expropriation of such an investment, except:
(a) for a public purpose;
(b) on a non-discriminatory basis;
(c) in accordance with due process of law and Article 1105 (1)15 and
(d) on payment of compensation in accordance with [subsequent paragraphs specifying valuation of expropriations and form and procedure of payment].

\section{B. Legal texts which address non-compensable regulation}

The relevant principles for the purposes of the European Convention of Human Rights are included in Article 1 of Protocol 1, concluded in 1952 and entered into force in 1954. Though this article, does not say so explicitly, it strongly implies that the duty to compensate is not applicable to normal regulation: ${ }^{16}$

"Every natural or legal person is entitled to the peaceful enjoyment of its possessions. No one should be deprived of his possessions except in the public interest and subject to the conditions provided for by the law and by the general principles of international law.

The proceeding provisions shall not, however, in any way impair the right of a state to enforce such laws as it deems necessary to control the use of property in accordance with the general interest or to secure the payment of taxes or other contributions or penalties" [italics added].

In 1961, the Harvard Draft Convention on the International Responsibility of States for Injuries to Aliens, drafted by Sohn and Baxter, assumed a taking to occur in the case of any "unreasonable interference with the use, enjoyment or disposal of property as to justify an interference that the owner thereof will not be able to use, enjoy or dispose of the property within a reasonable period of time after the inception of such interference". In its Article 10(5) it recognised the existence of a category of non-compensable takings:

"An uncompensated taking of an alien property or a deprivation of the use or enjoyment of property of an alien which results from the execution of tax laws; from a general change in the value of currency; from the action of the competent authorities of the State in the maintenance of public order, health or morality; or from the valid exercise of belligerent rights or otherwise incidental to the normal operation of the laws of the State shall not be considered wrongful".

15. Article 1105(1) provides: "each Party shall accord to investments of investors of another Party treatment in accordance with international law, including fair and equitable treatment and full protection and security".

16. The jurisprudence attached to the Convention by the European Court of Human Rights has consistently taken this line. 
Article 3 of the 1967 OECD ${ }^{17}$ Draft Convention on the Protection of Foreign Property, ${ }^{18}$ states that "no Party shall take any measures depriving, directly or indirectly, of his property a national of another Party.." unless four conditions are met according to recognised rules of international law. ${ }^{19}$ An accompanying note on the nature of obligation and its scope states the duty to compensate in a broad way:

"Article 3 acknowledges, by implication, the sovereign right of a State, under international law, to deprive owners, including aliens, of property which is within its territory in the pursuit of its political, social or economic ends. To deny such a right would be attempt to interfere with its powers to regulate - by virtue of its independence and autonomy, equally recognised by international law - its political and social existence. The right is reconciled with the obligation of the State to respect and protect the property of aliens by the existing requirements for its exercise - before all, the requirement to pay the alien compensation if his property is taken."

However, subsequent notes make clear that the concept of "taking" is not intended to apply to normal and lawful regulatory measures short of direct taking of property rights, but rather, to misuse of otherwise lawful regulation to deprive an owner of the substance of his rights:

4(a) “....By using the phrase 'to deprive...directly or indirectly ...' in the text of the Article it is, however, intended to bring within its compass any measures taken with the intent of wrongfully depriving the national concerned of the substance of his rights and resulting in such loss (e.g. prohibiting the national to sell his property of forcing him to do so at a fraction of the fair market price)" (emphasis in original).

4(b) “....Thus in particular, Article 3 is meant to cover "creeping nationalisation" recently practiced by certain states. Under it, measures otherwise lawful are applied in such a way:

“....as to deprive ultimately the alien of the enjoyment of value of his property, without any specific act being identifiable as outright deprivation. As instances may be quoted excessive or arbitrary taxation; prohibition of dividend distribution coupled with compulsory loans; imposition of administrators; prohibition of dismissal of staff; refusal of access to raw materials or of essential export or import licences."

The commentary to the American Law Institute's Restatement Third of Foreign Relations Law of the United States, ${ }^{20}$ was designed to assist in determining, inter alia, how to distinguish between an indirect expropriation and valid government regulation:

"A state is responsible as for an expropriation of property when it subjects alien property to taxation, regulation, or other action that is confiscatory, or that prevents, unreasonably

17. The OECD Code of Liberalisation of Capital Movements, through its provisions on the free disposal of blocked accounts and other non-resident owned assets, includes a dimension of preventing confiscation measures, in addition to the liberalisation disciplines per se of the Code. However, the Code is silent on the issue of the "right to regulate" in the context of this note.

18. OECD Draft Convention on Foreign Property, 12 October 1967 pp. 23-25.

19. The measures in question must be taken: (i) in the public interest, (ii) under due process of law; (iii) not be discriminatory; and furthermore, iv) just and effective compensation must be paid.

20. "Restatement of the Law Third, the Foreign Relations of the United States," American Law Institute, Volume 1, 1987, Section 712, Comment g. 
interferes with, or unduly delays, effective enjoyment of an alien's property or its removal from the state's territory... A state is not responsible for loss of property or for other economic disadvantage resulting from bona fide general taxation, regulation, forfeiture for crime, or other action of the kind that is commonly accepted as within the police power of states, if it is not discriminatory..." [italics added].

The MAI Negotiating Text was almost identical to the NAFTA provision. However, the MAI Commentary noted that by extending protection to "measures having equivalent effect" to expropriation, the text was intended to cover "creeping expropriation". MAI negotiators addressed the distinction between indirect expropriation and general regulations in the Report by the Chairman of the Negotiating Group (Chairman's Report) ${ }^{21}$ which was put forward at the later stage of the negotiations. In its Annex 3, Article 3 (Right to Regulate) and an interpretative note to Article 5 (Expropriation and Compensation) ${ }^{22}$ it is stated:

Article 3 "Right to Regulate"

"[a] a Contracting Party may adopt, maintain, or enforce any measure that it considers appropriate to ensure that investment activity is undertaken in a manner sensitive to healthy, safety or environmental concerns provided that such measures are consistent with this agreement".

Interpretative note to Article 5 "Expropriation and Compensation"

"This Article [] [is] intended to incorporate into the MAI existing international norms. The reference ... to expropriation or nationalisation and "measures tantamount to expropriation or nationalisation' reflects the fact that international law requires compensation for an expropriatory taking without regard to the label applied to it, even if title to the property is not taken. It does not establish a new requirement that Parties pay compensation for losses which an investor or investment may incur through regulation, revenue raising and other normal activity in the public interest undertaken by governments".

A Declaration adopted by the OECD Council of Ministers on April 28, $1998^{23}$ states that "the MAI would establish mutually beneficial international rules which would not inhibit the normal nondiscriminatory exercise of regulatory powers by governments and such exercise of regulatory powers would not amount to expropriation". ${ }^{24}$

\section{Criteria determining whether an indirect expropriation has occurred}

As discussed above, few legal texts attempted to address directly how to distinguish legitimate non-compensable regulations having an effect on the economic value of foreign investments and indirect expropriation, requiring compensation. Scholars recognised the existence of the distinction but did not shed much light on the criteria for making the distinction. This may reflect reluctance to

21. The Multilateral Agreement on Investment (Report by the Chairman of the Negotiating Group) DAFFE/MAI(98)17, 4 May 1998, available at http://www1.oecd.org/daf/mai/pdf/ng/ng9817e.pdf.

22. Id. pp. 13-15.

23. See OECD document C/MIN(98)16/FINAL.

24. For a discussion on regulatory expropriations in the MAI, see the article by R. Geiger "Regulatory Expropriations in International Law: Lessons from the Multilateral Agreement on Investment", N.Y.U. Environmental Law Journal, 2002, Volume 11, Number 1, pp. 94-109 at 104. 
attempt to lay down simple, clear rules in a matter that is subject to so many varying and complex factual patterns and a preference to leave the resolution of the problem to the development of arbitral decisions on a case-by-case basis. ${ }^{25}$. The two most prominent sources of such decisions were the Iran-United States Claims Tribunal ${ }^{26}$ and decisions arising under Article 1, Protocol 1 of the European Convention for the Protection of Human Rights. The recent period has seen a further body of jurisprudence, from cases based on NAFTA and bilateral investment agreements. At the same time, a new generation of investment agreements, including investment chapters of Free Trade Agreements has developed, which include criteria to articulate the difference between indirect expropriation and non-compensable regulation.

\section{A. Jurisprudence}

Although there are some "inconsistencies" 27 in the way some arbitral tribunals have distinguished legitimate non-compensable regulations having an effect on the economic value of foreign investments and indirect expropriation requiring compensation, a careful examination reveals that, in broad terms, they have identified the following criteria which look very similar to the ones laid out by the recent agreements: i) the degree of interference with the property right, ii) the character of governmental measures, i.e. the purpose and the context of the governmental measure, and iii) the interference of the measure with reasonable and investment-backed expectations.

\section{1) Degree of interference with the property right}

-- Severe economic impact

Most international decisions treat the severity of the economic impact caused by a government action as an important element in determining whether it rises to the level of an expropriation requiring compensation. International tribunals have often refused to require compensation when the governmental action did not remove essentially all or most of the property's economic value. There is broad support for the proposition that the interference has to be substantial in order to constitute

25. Christie wrote in 1962 that "it is evident that the question of what kind of interference short of outright expropriation constitutes a 'taking' under international law presents a situation where the common law method of case by case development is pre-eminently the best method, in fact probably the only method, of legal development". G. Christie "What Constitutes a Taking of Property under International Law?" British Yearbook of International Law, 1962 pp. 307-338. Sornarajah noted that the difficulty is "in the formulation of a theory that could be used as a predictive device so that there could be guidance as to whether the taking is a compensable or not. Here, though several efforts have been made at devising a theory capable of making the distinction, none has been successful". See op. cit. $n$. 9. Dolzer acknowledged after an extensive review of judicial precedent and state practice that "one cannot but admit at this stage that the law of indirect expropriation can be established, at this moment, on the basis of primary sources of international law, only in a very sketchy and rough manner". See op. cit. $n .7$.

26. The Iran-United States Claims Tribunal was established in 1981 in order to adjudicate claims by nationals of each country following the Iranian revolution. Its creation was pursuant to the Algiers Declarations which resolved the hostage crisis between Iran and the United States.

27. There is a view that the "inconsistent" case law which has been developed may simply reflect the different approaches of different treaties. According to this view, for example, the practice of the European Court of Human Rights on what "indirect expropriation" means could well be expected to differ from that of NAFTA tribunals, given the different wording, overall purpose and history of the treaties they have to refer to (European Convention of Human Rights on the one hand, and NAFTA on the other hand). 
expropriation, i.e. when it deprives the foreign investor of fundamental rights of ownership, or when it interferes with the investment for a significant period of time. Several international tribunals have found that a regulation may constitute expropriation when it substantially impairs the investor's economic rights, i.e. ownership, use, enjoyment or management of the business, by rendering them useless. Mere restrictions on the property rights do not constitute takings. The European Court of Human Rights $(\mathrm{ECHR})^{28}$ has found an expropriation where the investor has been definitely and fully deprived of the ownership of his/her property. If the investor's rights have not disappeared, but have only been substantially reduced, and the situation is not "irreversible", there will be no "deprivation" under Article 1, Protocol 1 of the European Convention of Human Rights. ${ }^{29}$

The first case under the Iran-United States Claims Tribunal ${ }^{30,31}$ was Starrett Housing, ${ }^{32}$ which dealt with the appointment of Iranian managers to an American housing project. The Tribunal concluded that an expropriation had taken place:

"[I]t is recognised by international law that measures taken by a State can interfere with property rights to such an extent that these rights are rendered so useless that they must be deemed to have been expropriated, even thought the State does not purport to have expropriated them and the legal title to the property formally remains with the original owner".

In the Sea-Land $d^{33}$ case one of the issues was alleged expropriation of a bank account. The Tribunal did not find any substantial deprivation of or interference with the claimant's rights to his account and rejected the claim by noting that the "account remains in existence and available in rials, at Sea-Land's disposal".

28. The European Court of Human Rights is the Court established by the Council of Europe under the Protection of Human Rights and Fundamental Freedoms Convention, to determine questions brought before it by individual petitioners or signatory states concerning violations of human rights by signatory states. It does not distinguish between foreign and domestic owners, but its distinctions as to compensable and non-compensable takings on a human rights basis is relevant.

29. See cases: Handyside v. United Kingdom, 24 Eur. Ct. H.R. (ser.A) at 29 (1976); Poiss v. Austria, 117 Eur. Ct.H.R. (ser. A)84, 108 (1987); Matos e Silva, Lda v. Portugal App. No. 15777/89, 24 Eur. Ct. H.R. rep. 573, 600-01 (1996). See for discussion H. Ruiz Fabri, "The Approach Taken by the European Court of Human Rights to the Assessment of Compensation for 'Regulatory Expropriations of the Property of Foreign Investors", N.Y.U. Environmental Law Journal, Volume 11, No 1, 2002 pp.148-173.

30. Sornarajah suggests that "although the awards of the Iran-United States Claims Tribunal have been a fruitful recent source for the identification of indirect takings, they dealt with takings that took place in the context of a revolutionary upheaval and the propositions the tribunal formulated may not have relevance outside the context of the events that attended the Iranian upheaval following the overthrow of the Shah of Iran". See op. cit. $n .9$ at 282. For instance, these actions and the context in which they occurred are, in many ways, different from the sorts of environmental and land-use regulations that have been the subjects of NAFTA claims.

31. For details on these cases see Seddigh and G. H. Aldrich, "What Constitutes a Compensable Taking of Property? The Decisions of the Iran-United States Claim Tribunal", The American Journal of International Law, Vol. 88 pp. 585-609.

32. Starret Housing Corp. v. Iran, 4 Iran-United States Cl. Trib. Rep. 122, 154 (1983).

33. Sea-Land Service Inc. v. Iran, 6 Cl. Trib. Rep.149 (1984). See Seddigh and Aldrich p. 656, op. cit. 31. 
In the Tippetts ${ }^{34}$ case, the Tribunal found an indirect expropriation because of the actions of a government-appointed manager, rather than because of his appointment per se, ${ }^{35}$ and equated that deprivation of property rights with a taking of property. ${ }^{36}$ The Tribunal said:

"While assumption of control over property by a government does not automatically and immediately justify a conclusion that the property has been taken by the government, thus requiring compensation under international law, such a conclusion is warranted whenever events demonstrate that the owner was deprived of fundamental rights of ownership and it appears that the deprivation is not merely ephemeral...".

In the NAFTA context, in the Pope \& Talbot case, ${ }^{37}$ the Tribunal found that although the introduction of export quotas resulted in a reduction of profits for the Pope \& Talbot company, sales abroad were not entirely prevented and the investor was still able to make profits. It stated: “....mere interference is not expropriation; rather, a significant degree of deprivation of fundamental rights of ownership is required". ${ }^{38}$

In S.D. Myers ${ }^{39}$ a United States company, which operated a PCB remediation facility in the United States, alleged that Canada violated NAFTA Chapter 11 by banning the export of PCB waste to the United States. The Tribunal also distinguished regulation from expropriation primarily on the basis of the degree of interference with property rights: "expropriations tend to involve the deprivation of ownership rights; regulations [are] a lesser interference". ${ }^{40}$

In Marvin Roy Feldman Karpa (CEMSA) v. United Mexican States, ${ }^{41}$ CEMSA, a registered foreign trading company and exporter of cigarettes from Mexico, was allegedly denied the benefits of the law that allowed certain tax refunds to exporters and claimed expropriation under NAFTA Article 1110. The Tribunal found that there was no expropriation since "the regulatory action has not deprived the Claimant of control of his company, interfered directly in the internal operations of the company or displaced the Claimant as the controlling shareholder. The Claimant is free to pursue other continuing

34. Tippetts v. TAMS-AFFA Consulting Engineers of Iran, 6 Cl. Trib. 219 (1984).

35. While Tippetts was able to work with the Iranian appointed manager for some months and reestablished its rights as a partner, its personnel left Iran following the seizure of the American Embassy and the new manager broke off communications with Tippetts by refusing to respond to its letters and telexes.

36. In this case, the Tribunal said that it "prefers the term 'deprivation' to the term 'taking', although they are largely synonymous, because the latter may be understood to imply that the government has acquired something of value, which is not required".

37. Pope \& Talbot Inc. v. Canada, see op. cit. $n$. 6.

38. In addition, the Tribunal stated that: "Regulations can indeed be characterised in a way that would constitute creeping expropriation....Indeed, much creeping expropriation could be conducted by regulation, and a blanket exception for regulatory measures would create a gaping loophole in international protection against expropriation", see Award paragraph 99.

39. S.D. Myers Inc. v. Government of Canada, see op. cit. n. 6.

40. The Tribunal added that: "the distinction between expropriation and regulation screens out most potential cases of complaints concerning economic intervention by a state and reduces the risk that governments will be subject to claims as they go about their business of managing public affairs".

41. In this case, Marvin Feldman, a United States citizen, submitted claims on behalf of CEMSA. ICSID Case No. ARB(AF)/99/1, Award of 16 December 2002, pp. 39-67 at 59. 
lines of business activity.... Of course, he was effectively precluded from exporting cigarettes.....However, this does not amount to Claimant's deprivation of control of his company".

The European Court of Human Rights, in the most widely cited case under Article 1, Protocol 1 of the European Convention of Human Rights (see above), Sporrong and Lönnroth v. Sweden ${ }^{42}$ (1982), did not find indirect expropriation to have occurred as a result of land use regulations that affected the claimant's property because:

“...although the right [of peaceful enjoyment of possessions] lost some of its substance, it did not disappear... The Court observes in this connection that the [claimants] could continue to utilise their possessions and that, although it became more difficult to sell properties [as a result of the regulations], the possibility of selling subsisted".

A different approach was taken by the arbitral Tribunal in the case CME (the Netherlands) $v$. the Czech Republic. ${ }^{43} \mathrm{CME}$, the Claimant, had purchased a joint venture media company in the Czech Republic and alleged, inter alia, breach of the obligation of the [host country] not to deprive the investor of its investment ${ }^{44}$ because of the actions of the national Media Council. The Tribunal, citing inter alia, the Tippets and Metalclad cases, found that an expropriation had occurred because "the Media Council's actions and omissions...caused the destruction of the [joint-venture's] operations, leaving the [joint venture] as a company with assets, but without business". ${ }^{45}$ It stated also that although "regulatory measures are common in all types of legal and economic systems in order to avoid use of private property contrary to the general welfare of the host state" measures taken by the host country did not fall under this category. It therefore concluded that,

“Expropriation of [the company's] investment is found a consequence of the [host country's] actions and inactions as there is no immediate prospect at hand that the [joint venture] will be reinstated in a position to enjoy an exclusive use of the license..."47

Another relevant decision is the Revere Copper ${ }^{48}$ case (1980). The case arose from a concession agreement - which was to last for twenty five years - made by a subsidiary of the Revere Copper company with the government of Jamaica. The government, despite a stabilisation clause in the agreement ensuring that taxes and other financial liabilities would remain as agreed for the duration of the concession, increased the royalties. The company found it difficult to continue operations and

42. In this case, long-term expropriation permits (23 and 8 years) had been granted by the city of Stockholm in respect of the applicant's properties. These did not of themselves expropriate the property, but gave local authorities the power to do so, should they so decide in the future. Sporrong and Lönnorth complained that it was impossible for them to sell these properties and that it amounted to an interference with their right to peaceful enjoyment of possessions. The Swedish government, by contrast, emphasised the public purpose of the permits system and the intentions of the city of Stockholm to make improvements for the general good. See R. Higgins, op. cit. n. 12 at 276-77.

43. CME (Netherlands) v. Czech Republic (Partial Award) (13 September, 2001) available at www.mfcr.cz/scripts/hpe/default.asp

44. Article 5 of the 1991 Bilateral Investment Treaty between the Netherlands and the Czech Republic.

45. See CME para 591, p. 166.

46. Idem para. 603 , p. 170.

47. Id. Para. 607, p. 171.

48. Revere Copper \& Brass Inc. v. Overseas Private Investment Corporation, 56 International Legal Materials 258. 
closed operations and claimed compensation under its insurance contract. The Arbitral Tribunal, ${ }^{49}$ assuming that the contract was governed by international law, found that there had been a taking by the government and observed: $:^{50}$

"In our view, the effects of the Jamaican Government's actions in repudiating its long term commitments to RJA (the subsidiary of RC), have substantially the same impact on effective control over use and operation as if the properties were themselves conceded by a concession contract that was repudiated...."

Although the insurance agency (OPIC) argued that RJA still had all the rights and property and that it could operate as it did before, the Tribunal responded that "this is may be true but...we do not regard RJA's control of the use and operation of its properties as any longer effective in view of the destruction by government action of its contract rights".

-- Duration of the regulation

The duration of the regulation could be another criterion of whether the regulation has had a severe enough impact on property to constitute a taking. ${ }^{51,52}$

The Iran-United States Claims Tribunal has acknowledged this was an issue but it has had little difficulty in finding that the appointment of "temporary" managers may constitute a taking of property, when the consequent deprivation of property rights is not "merely ephemeral" (in Tippetts, Phelps Dodge and Saghi cases).

A widely cited example where the temporal factor has played an important role is the 1979 case of Hauer v. Land Rheinland-Pfalz, ${ }^{53}$ The facts relate to a German winegrower who had to apply for a state permit for planting new vines. While the application was pending, the European Commission issued an order prohibiting the planting of that type of vine for three years. The plaintiff brought her claim before the European Court of Justice which found that there was no violation of Hauer's property rights emphasising in particular that the EEC order was to be valid only for a transitory period of three years.

In S.D. Myers v. Canada, ${ }^{54}$ the NAFTA Tribunal accepted that "in some contexts and circumstances it would be appropriate to view a deprivation as amounting to an expropriation even if it were partial and temporary". However, it concluded that Canada's initiative "was only valid for a time". Under these circumstances, "an opportunity was delayed" but no indirect expropriation could be found.

-- Economic impact as the exclusive criterion

49. The Tribunal was set up under the American Arbitration Association.

50. $\quad$ For discussion see R. Higgins, pp. 331-37, op. cit. n.12, Sornarajah, p. 301, op. cit. no. 9 at 301 and R. Dolzer op. cit. $n .7$ at 51-52.

51. J.M. Wagner, "International Investment, Expropriation and Environmental Protection", Golden Gate University Law Review (1999), Vol.29, No 3; pp. 465-538.

52. Prof Christie, in its 1962 article, discusses when a "temporary seizure" ripens into an expropriation op. cit. no. 25 .

53. See R. Higgins, op. cit. n 12, Dolzer, op. cit. n. 7, Ruiz Fabri, op. cit. n.29.

54. See op. cit. n. 6 . 
There is no serious doubt that the severity of the impact upon the legal status and the practical impact on the owner's ability to use and enjoy his/her property is one of the main factors in determining whether a regulatory measure effects an indirect expropriation. What is more controversial "is the question of whether the focus on the effect will be the only and exclusive relevant criterion - 'sole effect doctrine' - or whether the purpose and the context of the governmental measure may also enter into the takings analysis" ${ }^{\prime 5}$. The outcome in any case may be affected by the specific wording of the particular treaty provision. From the doctrine and the case examination, it seems however that the balanced approach is pre-dominant.

A few cases have focused on the effect of the owner as the main factor in discerning a regulation from a taking. In the Tippetts case, the Iran-United States Tribunal held that:

"the intent of the government is less important than the effects of the measures on the owner, and the form of the measures of control or interference is less important than the reality of their impact".

In the Phelps Dodge case, ${ }^{56}$ a transfer of management was made pursuant to a pre-revolutionary law designed to prevent the closure of factories, ensure payments due to the workers, and protect any debts owed to the Government, which in this case included loans made by a bank that had been nationalised in 1979. Citing Tippetts the Iran-United States Tribunal stated that:

"The Tribunal fully understands the reasons why the respondent felt compelled to protect its interests through this transfer of management, and the Tribunal understands the financial, economic and social concerns that inspired the law pursuant to which it acted, but those reasons and concerns cannot relieve the Respondent of the obligation to compensate Phelps Dodge for its loss".

In the Metalclad case ${ }^{57}$ in the context of the NAFTA, Metalclad alleged that its subsidiary COTERIN's attempt to operate a hazardous waste landfill that it constructed in the municipality of Guadalcázar, had been thwarted by measures attributable to Mexico. Metalclad commenced an action under the NAFTA, claiming that an ecological decree promulgated after the claim was made, violated Article 1110 requiring compensation for expropriation. The Tribunal found a violation of NAFTA Article 1110 and stated that in order to decide on an indirect expropriation, it "need not decide or consider the motivation, nor intent of the adoption of the Ecological Decree". The Tribunal stated:

"expropriation under NAFTA includes not only open, deliberate and acknowledged takings of property, such as outright seizure or formal or obligatory transfer of title in favour of the host State, but also covert or incidental interference with the use of property which has the effect of depriving the owner, in whole or in significant part, of the use of reasonably-to-beexpected economic benefit of property even if not necessarily to the obvious benefit of the host State".]

The case Compañía del Desarrollo de Santa Elena v. Costa Rica, ${ }^{58}$ although referred to a direct expropriation, not an indirect taking, has attracted particular attention because the panel expressly

55. Dolzer, see op. cit. n. 2. at 79.

56. Phelps Dodge, 10 Iran-United States Cl. Trib. Rep. at 130.

57. $\quad$ Metalclad Corporation v. United Mexican States (Tribunal Decision August 30, 2000).

58. Compañía del Desarrollo de Santa Elena S.A. v. Republic of Costa Rica, ICSID Case No. ARB/96/1. (February 17, 2000). 
stated that the environmental purpose had no bearing on the issue of compensation. In this case, the claimant (Company Santa Elena) was formed primarily for the purpose of purchasing Santa Elena - a 30 kilometre terrain in Costa Rica - with the intention of developing it as a tourist resort. In 1978, Costa Rica issued an expropriation decree for Santa Elena aiming at declaring it a preservation site. Twenty years of legal proceedings between the Parties finally ended with a decision by an ICSID panel. While this case concerns a direct expropriation where the issue was the day of the taking for purposes of determining compensation, the panel, citing the Tippett case, indicated that a compensable expropriation could occur through measures of a state which deprives the owner of "access to the benefit and economic use of his property" or "has made those [property] rights practically useless".. The panel held that:

"While an expropriation or taking for environmental reasons may be classified as a taking for a public purpose, and thus be legitimate, the fact that the property was taken for this reason does not affect either the nature or the measure of the compensation to be paid for the taking. That is, the purpose of protecting the environment for which the Property was taken does not alter the legal character of the taking for which adequate compensation must be paid. $^{59}$ The international source of the obligation to protect the environment makes no difference". It also added that:

"Expropriatory environmental measures - no matter how laudable and beneficial to society as a whole - are, in this respect, similar to any other expropriatory measures that a state may take in order to implement its policies: where property is expropriated, even for environmental purposes, whether domestic or international, the state's obligation to pay compensation remains".

2) Character of governmental measures, i.e. the purpose and the context of the governmental measure

A very significant factor in characterising a government measure as falling within the expropriation sphere or not, is whether the measure refers to the State's right to promote a recognised "social purpose" considerations of the public health, safety, morals or welfare will normally lead to a conclusion that there has been no "taking"". 62 "Non-discriminatory measures related to anti-trust, consumer protection, securities, environmental protection, land planning are non-compensable takings since they are regarded as essential to the functioning of the state". ${ }^{63}$

In the context of the jurisprudence of the European Court of Human Rights the State may affect control on activities by individual by imposing restrictions which may take the form of planning

59. For this reason, the Tribunal did not analyse the detailed evidence submitted regarding what Costa Rica referred to as its international obligations to preserve the unique Santa Elena ecological site.

60. The Iran-US Claims Tribunal: Its contribution to the Law of State Responsibility, see op. cit. $n .6$ at 200.

61. See B.H. Weston, op. cit. n. 3 at 116.

62. Christie see op. cit. n. 25 at 338.

63. M. Sornarajah, op. cit. n.9. 
controls, environmental orders, rent controls, import and export laws, economic regulation of professions, [and] the seizure of properties for legal proceedings or inheritance laws" ${ }^{64}$

In the context of the Article 1 of Protocol 1 of the European Convention of Human Rights, the European Court has given States a very wide margin of appreciation concerning the establishment of measures for the public interest and has recognised that it is for national authorities to make the initial assessment ${ }^{65}$ of the existence of a public concern warranting measures that result in a "deprivation" of property. The Court held that the state's judgement should be accepted unless exercised in a manifestly unreasonable way.

In addition, the Court has adopted a common approach to "deprivations" and "controls" of use of property. In either case, there has to be a reasonable and foreseeable national legal basis for the taking, because of the underlying principle in stability and transparency and the rule of law. ${ }^{66}$ In relation to either deprivation or control of use, the measures adopted must be proportionate. The Court examines whether the interference at issue strikes a reasonable balance between the demands of the general interest of the community and the private interests of the alleged victims of the deprivation and whether an unjust burden has been placed on the claimant. In order to make this assessment, the Court proceeds into a factual analysis insisting that precise factors which are needed to be taken into account vary from case to case. In the James case $^{67}$ for example, the Court said that:

"The taking of property in pursuance of a policy calculated to enhance social justice within the community can properly be described as being 'in the public interest'. In particular, the fairness of a system of law governing the contractual or property rights of private parties is a matter of public concern and therefore legislative measures intended to bring about such fairness are capable of being in the 'public interest', even if they involve the compulsory transfer of property from one individual to another".

In the Sporrong and Lönnroth v. Sweden case, the Court stated that Article 1 contains "three distinct rules":

"The first rule, which is of a general nature, enounces the principle of peaceful enjoyment of property; it is set out in the first sentence of the first paragraph. The second rule covers deprivation of possessions and subjects it to certain conditions; it appears in the second sentence in the same paragraph. The Third rule recognises that the States are entitled, amongst other things, to control the use of property in accordance with the general interest, by enforcing such laws as they deem necessary for the purpose; it is contained in the second paragraph".

64. See D.J. Harris et al., referring to the jurisprudence of the European Court of Human Rights in the "Law of the European convention on Human Rights", (1995) at 535.

65. The state margin of appreciation is justified by the idea that national authorities have better knowledge of their society and its needs, and are therefore 'better placed than [an] international [court] to appreciate what is in the public interest'”. See James v. United Kingdom, 98 Eur. Ct. H.R. (ser. A) 9, 32 (1986).

66. See H. Mountfield, "Regulatory Expropriations in Europe: the Approach of the European Court of Human Rights", N.Y.U. Environmental Law Journal, Volume 11, No 1, 2002 pp. 136-147.

67. This case concerns a reform undertaken by the United Kingdom regarding the right of individuals with long leases to acquire the freehold of their leasehold property. This reform, according to James, the Claimant, "deprived" the freeholders of their property since they could neither refuse to sell nor set the price for it. See op. cit. n. 65 . 
The European Court of Human Rights found no expropriation as a result of the first test, yet found compensation to be required as a result of the second test. Under the "fair balance test", it found that over the years the state had failed to take proper account of individual interests involved. Since the state had neither shortened the temporal effect of the rules nor paid compensation, the court rules that the State had placed "an individual and excessive burden" on plaintiffs and therefore acted in violation of Article 1.

In the NAFTA context, in the S.D. Myers case $^{68}$, the Tribunal found that the expression "tantamount to expropriation" in NAFTA's Article 1110(1), was understood as "equivalent to expropriation" and added:

"Both words require a tribunal to look at the substance of what has occurred and not only at form. A tribunal should not be deterred by technical or facial considerations from reaching a conclusion that an expropriation or conduct tantamount to an expropriation has occurred. It must look at the real interests involved and the purpose and effect of the government measure".

In the case of Tecnicas Medioambientales Tecmed S.A, v. The United Mexican States, ${ }^{69}$ the investor, Técnicas Medioambientales Techmed, S.A., filed a claim with ICSID alleging that the Mexican government's failure to re-license its hazardous waste site contravened various rights and protections set out in the bilateral investment treaty (BIT) between Spain and Mexico and was an expropriatory act. The Tribunal in order to determine whether the acts undertaken by Mexico were to be characterised as expropriatory, citing the ECHR's practice, considered "whether such actions or measures are proportional to the public interest presumably protected thereby and the protection legally granted to investments, taking into account the significance of such impact plays a key role in deciding the proportionality". ${ }^{70}$ It added that: "there must be a reasonable relationship of proportionality between the charge of weight imposed to the foreign investor and the aim sought to be realised by an expropriatory measure". ${ }^{71}$

-- "Police Powers" of the State

The notion that the exercise of the State's "police powers" will not give rise to a right to compensation has been widely accepted in international law. However, the "police powers" doctrine is viewed by some not as a criterion which is weighed in the balance with other factors, but as a controlling element which exempts automatically the measure from any duty for compensation.

One commentary on the law on expropriation and the State's "police powers" is the commentary to the American Law Institute's Restatement (Third) of Foreign Relations Law of the United States ${ }^{72}$ which was designed to assist, inter alia, in determining how to distinguish between an indirect expropriation and valid governmental regulation: “...a state is not responsible for loss of property or for other economic disadvantage resulting from bona fide general taxation, regulation, forfeiture for

68 See op. cit. n.6.

69. Tecnicas Medioambientales Tecmed S.A, v. The United Mexican States, ICSID Award Case No. ARB (AF)/00/2.

70. Idem. Para. 122.

71. Idem.

72. Restatement of the Law Third op. cit. n. 20 Section 712, Comment g. 
crime, or other action of the kind that is commonly accepted as within the police power of the states, if it is not discriminatory...".

In the context of the Iran-United States Claims Tribunal, the only award in which an allegation of taking was rejected on the grounds of police power regulations was Too v. Greater Modesto Insurance Associates, ${ }^{73}$ where the claimant sought compensation for the seizure of his liquor licence by the United States Internal Revenue Service. The Tribunal said:

“...A State is not responsible for loss of property or for other economic disadvantage resulting from bona fide general taxation or any other action that is commonly accepted as within the police power of States, provided it is not discriminatory and is not designed to cause the alien to abandon the property to the State or to sell it at a distress price..."]

The Tribunal in the Lauder $^{74}$ case said about the interference with property rights that, "....Parties to [the Bilateral] Treaty are not liable for economic injury that is the consequence of bona fide regulation within the accepted police powers of the State".

In the case of Tecnicas Medioambientales Tecmed S.A, v. The United Mexican States,${ }^{75}$ although the Tribunal found an expropriation, it has stated that: "the principle that the State's exercise of its sovereign power within the framework of its police power may cause economic damage to those subject to its powers as administrator without entitling them to any compensation whatsoever is undisputable".

\section{3) Interference of the measure with reasonable investment-backed expectations}

Another criterion identified is whether the governmental measure affects the investor's reasonable expectations. In these cases the investor has to prove that his/her investment was based on a state of affairs that did not include the challenged regulatory regime. The claim must be objectively reasonable and not based entirely upon the investor's subjective expectations.

In the 1934 Oscar Chinn ${ }^{76}$ case, the Permanent Court of International Justice (P.C.I.J.) did not accept the contention of indirect taking ${ }^{77}$ noting that, in those circumstances, a granting of a de facto monopoly did not constitute a violation of international law and that "favourable business conditions and good will are transient circumstances, subject to inevitable changes": ${ }^{78}$

"No enterprise...can escape from the chances and hazards resulting from general economic conditions. Some industries may be able to make large profits during a period of general prosperity, or else by taking advantage of a treaty of commerce or of an alteration in customs

73. Award December 29, 1989, 23 Iran-United States Cl. Trib. Rep.378. Also see Seddigh and G. H. Aldrich op. cit. no. 31 .

74. Lauder (U.S.) v. Czech Republic (Final Award) (September 3, 2002) available at www.mfcr.cz/scripts/hpe/default.asp

75. See op. cit. n. 69.

76. See op. cit. n. 6 .

77. The P.C.I.J. employed "effective deprivation", as the standard for determining if the interference was sufficiently serious to constitute a compensable taking.

78. H. Seddigh, "What level of Host State Interference Amounts to a Taking under Contemporary International Law? Journal of World Investment, 2001, Vol. 2, No. 4, pp. 631-84 at 646. 
duties; but they are also exposed to the danger of ruin or extinction if circumstances change. Where this is the case, no vested rights are violated by the State".

The Iran-U.S. Claims Tribunal in Starett Housing Corp. v. Iran $^{79}$ took into account the reasonable expectations of the investor:

"Investors in Iran, like investors in all other countries, have to assume a risk that the country might experience strikes, lock-outs, disturbances, changes of economic and political system and even revolution. That any of these risks materialised does not necessarily mean that property rights affected by such events can be deemed to have been taken".

In Marvin Roy Feldman Karpa (CEMSA) v. United Mexican States ${ }^{80}$ the NAFTA Tribunal noted:

"Governments, in their exercise of regulatory power, frequently change their laws and regulations in response to changing economic circumstances or changing political, economic or social considerations. Those changes may well make certain activities less profitable or even uneconomic to continue....".

In Tecnicas Medioambientales Tecmed S.A, v. The United Mexican States, ${ }^{81}$ the Tribunal attempted to determine whether the Mexican government's measures were "reasonable with respect to their goals, the deprivation of economic rights and the legitimate expectations of who suffered such deprivation". "...Even before the Claimant made its investment, it was widely known that the investor expected its investments in the Landfill to last for a long term and that it took this into account to estimate the time and business required to recover such investment and obtain the expected return upon making its tender offer for the acquisition of the assets related to the Landfill. To evaluate if the actions attributable to the Respondent - as well as the Resolution ${ }^{82}$ - violate the Agreement, such expectations should be considered legitimate and should be evaluated in light of the Agreement and of international law" ${ }^{83}$ Based on this and the fact that the "Resolution" was not proportionate to the "infringements" ${ }^{84}$ by Techmed, the Tribunal found that the "Resolution" and its effects amounted to an expropriation.

79. See op. cit. n. 32 .

$80 \quad$ See op. cit. n. 41.

81. See op. cit. n. 75 .

82. Resolution was the decision not to re-new the license.

83. Techmed Award, para. 50.

84. "All the infringements committed were either remediable or remediated or subject to minor penalties". Techmed Award para 148. 


\section{B. $\quad$ State practice}

As a response to the growing jurisprudence in this field, the recently concluded $\boldsymbol{U S}$-Free Trade Agreements with Australia $^{85}$, Chile $^{86}$, Central America ${ }^{87}$, Morocco $^{88}$ and $^{\text {Singapore }}{ }^{89}$ and the new US model BIT ${ }^{90}$ provide explicit criteria of what constitutes an indirect expropriation. In the Annexes on Expropriation, they state that:

The determination of whether an action or series of actions by a Party, in a specific fact situation, constitutes an indirect expropriation, requires a case-by-case, fact-based inquiry that considers, among other factors;

(i) the economic impact of the government action, although the fact that an action or series of actions by a Party has an adverse effect on the economic value of an investment, standing alone, does not establish that an indirect expropriation has occurred;

(ii) the extent to which the government action interferes with distinct, reasonable, investment-backed expectations; and

(iii) the character of the government action.

In addition, they address indirect expropriation and the right to regulate:

Except in rare circumstances, non-discriminatory regulatory actions by a Party that are designed and applied to protect legitimate public welfare objectives, such as public health, safety and the environment, do not constitute indirect expropriations.

The updated Canada's model Foreign Investment Promotion and Protection Agreement (FIPA) ${ }^{91}$ stipulates that it:

"incorporates a clarification of indirect expropriation which provides that, except in rare circumstances, non-discriminatory measures designed and applied to protect legitimate public welfare objectives, such as health, safety and the environment, do not constitute indirect expropriation and are not subject, therefore, to any compensation requirements".

85 US-Australia Free Trade Agreement signed on March 1, 2004, [Annex 11-B, Article 4(b)].

86. The US-Chile Free Trade Agreement was signed on June 6, 2003 (Annex 10-D).

87 US-Central America Free Trade Agreement (CAFTA) signed on January 28, 2004, (Annex 10-C). The Central American countries are: Costa Rica, El Salvador, Guatemala, Honduras, Nicaragua.

88 US-Morocco Free Trade Agreement signed on June 15, 2004 (Annex 10-B).

89 US Trade representative Robert Zoellick to Singapore Minister of Trade and Industry, George Yeo on 6 May, 2003.

90 For the text of the model BIT see http://www.state.gov/e/eb/rls/prsrl/2004/28923.htm

91 For the text of the new FIPA model see http://www.dfait-maeci.gc.ca/tna-nac/what_fipa-en.asp 


\section{Summing up}

- Expropriation (direct and indirect) requires compensation, based on clearly set rules of customary international law. However, while determination of a direct expropriation is relatively straightforward to make, determining whether a measure falls into the category of indirect expropriation has required tribunals to undertake a thorough case-by-case examination and a careful consideration of the specific wording of the treaty.

- The line between the concept of indirect expropriation and non-compensable regulatory governmental measures has not been systematically articulated. However, a close examination of the relevant jurisprudence reveals that, in broad terms, there are some criteria that tribunals have used to distinguish these concepts: i) the degree of interference with the property right, ii) the character of governmental measures, i.e. the purpose and the context of the governmental measure, and iii) the interference of the measure with reasonable and investment-backed expectations.

- Tribunals, instead of focusing exclusively on the "sole effect" on the owner, have also often taken into account the purpose and proportionality of the governmental measures to determine whether compensation was due. Thus a number of cases were determined on the basis of recognition that governments have the right to protect, through non-discriminatory actions, inter alia, the environment, human health and safety, market integrity and social policies without providing compensation for any incidental deprivation of foreign owned property.

- Up to now only a handful of international agreements articulated this difference. Recently, new generation of investment agreements, including investment chapters of Free Trade Agreements, have introduced specific language and established criteria to assist in determining whether an indirect expropriation requiring compensation has occurred. These criteria are consistent with those emerging from arbitral decisions.

- At the same time, prudence requires to recognise that the list of criteria which can be identified today from state practice and existing jurisprudence is not necessarily exhaustive and may evolve. Indeed, new investment agreements are being concluded at a very fast pace and the number of cases going to arbitration is growing rapidly. Case-by-case consideration which may shed additional light will continue to be called for. 